\title{
PENDAMPINGAN GURU TK DAN SD DALAM MELAKSANAKAN PENELITIAN TINDAKAN DI MASA PANDEMI COVID-19
}

\author{
Dek Ngurah Laba Laksana1), Yosefina Uge Lawe'), dan Efrida Ita ${ }^{3)}$ \\ ${ }^{1,2)}$ Program Studi PGSD, STKIP Citra Bakti \\ ${ }^{3)}$ Program Studi Pendidikan Guru PAUD, STKIP Citra Bakti \\ 1)laba.laksana@citrabakti.ac.id, ${ }^{2)}$ yosefinagelawe@gmail.com, ${ }^{3)}$ evoletelvo@gmail.com
}

\section{Histori artikel}

Received:

31 Januari 2021

Accepted:

10 Maret 2021

Published:

19 April 2021

\begin{abstract}
Abstrak
Telah teridentifikasi bahwa pemahaman dan keterampilan guru dalam melaksanakan penelitian tindakan masih rendah. Di sisi lain, masa pandemi ini menyulitkan guru dalam melaksanakan tindakan kelas. Untuk itu perlu dilakukan pendampingan dengan tetap memperhatikan protokol kesehatan di masa pandemi COVID-19. Tujuan dari kegiatan pendampingan ini adalah untuk meningkatkan keterampilan guru merencanakan, melaksanakan, menyajikan, dan mempublikasikan hasil penelitian tindakan kelas di masa pandemi COVID-19. Metode pelaksanaan pendampingan melalui ceramah presentasi, tatap muka, dan diskusi luring dan daring). Data yang diperoleh, kemudian dianalisis secara deskriptif. Kegiatan dilaksanakan di TK dan SD Widiatmika, Kabupaten Badung, Bali dengan melibatkan 31 guru TK dan SD dari Yayasan Widiatmika. Hasil kegiatan adalah terjadi peningkatan pemahaman tentang hakekat penelitian tindakan, peningkatan keterampilan dalam melakukan perencanaan penelitian tindakan kelas, pengembangan instrumen penelitian tindakan kelas, teknik menyajikan data hasil penelitian, pengembangan proposal dan pelaksanaan penelitian, diseminasi/seminar hasil penelitian, dan publikasi karya ilmiah. Peningkatan kompetensi guru tersebut dari kategori cukup baik (64\%) menjadi kategori sangat baik (92\%).
\end{abstract}

Kata-kata Kunci: kompetensi guru, pengembangan profesiguru, penelitian tindakan. 
Abstract. It has been identified that teachers' understanding and skills in carrying out action research are still low. On the other hand, this pandemic period made it difficult for teachers to carry out classroom actions. For this reason, assistance is needed while still paying attention to health protocols during the COVID-19 pandemic. The purpose of this mentoring activity is to improve the skills of teachers to plan, implement, present and publish the results of classroom action research during the COVID-19 pandemic. The method of implementing mentoring is through lecture presentations, face to face, and discussions (face to face and online). The data obtained were then analyzed descriptively. The activities were carried out in Widiatmika Kindergarten and Elementary School, Badung Regency, Bali. By involving 31 kindergarten and elementary school teachers from the Widiatmika Foundation. The result of the activity is an increase in understanding of the nature of action research, increased skills in planning classroom action research, developing classroom action research instruments, techniques for presenting research data, developing proposals and implementing research, disseminating research results / seminars, and publishing scientific papers. The increase in teacher competence from the fairly good category $(64 \%)$ to the very good category $(92 \%)$.

Keywords: teacher competency, teacher professional development, action research

\section{PENDAHULUAN}

Guru sebagai sebuah profesi, dituntut memiliki kemampuan dalam merencanakan, melaksanakan, dan mengevaluasi, pembelajaran yang dilakukan (Dasna, Laksana, dan Sudatha, 2015; Laksana, 2019a). Selain tugas pokok tersebut, tentunya guru juga ditugaskan dalam menghasilkan karya ilmiah, yang merupakan bentuk pelaporan inovasi pembelajaran yang dilakukan (Ditjen GTK, 2016). Karya ilmiah ini menjadi kewajiban bagi guru yang telah tersertifikasi dan naik pangkat ke jenjang IIIB ke atas (PermenPAN RB, 2009, Noorjannah, 2014).

Hasil penelitian menunjukkan bahwa kompetensi guru yang terjabar dalam empat kompetensi dasar guru sudah baik. Namun pada aspek penulisan karya ilmiah, kemampuan guru masih kurang (Laksana dan Rawa, 2014). Temuan lainnya menunjukkan bahwa pemahaman guru dalam menulis karya ilmiah masih rendah (Sodiq, Suryadi, dan Ahmad, 2014). Rendahnya pemahaman tersebut, disebabkan karena fasilitas dan wadah kegiatan pendampingan yang masih terbatas. Padahal pada dasarnya, penulisan karya ilmiah yang merupakan hasil penelitian tindakan kelas, bukanlah sesuatu yang baru. Penelitian tindakan dilaksanakan guru sejalan dalam pelaksanaan pembelajaran. Karena pada dasarnya, guru melaksanakan pembelajaran dengan sebuah strategi/model/teknik untuk mencapai tujuan pembelajaran yang diinginkan (Susantini, Rahayu, Budiono, dan Raharjo, 2016; Yulika, Kasman, dan Masta, 2016). Apalagi di era pembelajaran 4.0 saat ini, guru dituntun mempunyai wawasan terkait pembelajaran di era big data dalam menunjang proses pembelajaran daring (Laksana, 2019b).

Kompetensi guru dalam melaksanakan sebuah penelitian tindakan merupakan pemicu terjadinya peningkatan kualitas pembelajaran di kelas (Rispawati dan Herianto, 2019). Namun, jika dalam pelaksanaannya, guru tidak mampu, maka sensitivitas guru terhadap memecahkan permasalahan pembelajaran tidak akan berkembang (Laksana, Dinatha, dan Upayogi, 2020; Lawa dkk., 2020). 
Ketidakmampuan guru ini berdampak pada hasil belajar siswa dan kualitas proses pembelajaran tidak akan mengalami peningkatan. Permasalahan lain yang muncul adalah terbatasnya karya ilmiah guru yang dipublikasikan pada jurnal ilmiah. Padahal, karya ilmiah tersebut merupakan sumber informasi yang dibutuhkan oleh guru-guru lainnya sebagai rujukan ketika menghadapi masalah yang sama (Dwijayanti, Marlena, Patrikha, dan Parjono, 2017).

Jika semakin banyak guru yang menghasilkan karya ilmiah, semakin banyak alternatif solusi untuk memperbaiki kualitas proses dan hasil belajar. Hal ini berarti penelitian tindakan yang didiseminasikan guru mempunyai dampak yang luas bagi guru dan pemerhati pendidikan (Supriyanto, 2017; Sugiyarti, Nurfitriani, dan Vebrian, 2019).

Permasalahan guru dalam mengembangkan karya ilmiah juga terjadi pada sekolah di bawah Yayasan Widiatmika, Jimbaran, Kabupaten Badung, Bali. Berdasarkan hasil wawancara dengan kepala TK dan SD Widiatmika, teridentifikasi bahwa guru di sekolah tersebut, jarang melakukan penelitian Tindakan. Dalam wawancara tersebut juga disampaikan bahwa, kendala pemahaman dan keterampilan guru terkait penelitian Tindakan masih rendah. Di sisi lain, di masa pandemi, kegiatan belajar berlangsung secara daring atau dikenal dengan Belajar dari Rumah (Safrizal, Putra, Sofyan, dan Bimo, 2020). Salah satu sekolah yang melaksanakan BDR adalah sekolah di bawah Yayasan Widiamika yaitu TK Widiatmika dan SD Widiatmika.Karena proses belajar yang berlangsung secara daring, maka bentuk penelitian tindakan pun dilaksanakan dengan menyesuaikan kondisi yang ada. Pelaksanaan penelitian dilakukan juga secara daring. Penelitian tindakan dilaksanakan secara daring, karena proses dan penilaian pembelajaran juga dilaksanakan secara daring.

Untuk itu, perlu dilakukan kegiatan pendampingan terhadap guru, dalam mengembangkan kompetensi guru khususnya untuk guru TK dan SD di Sekolah Widiatmika. Tujuan dari kegiatan pendampingan ini adalah untuk meningkatkan keterampilan guru merencanakan, melaksanakan, menyajikan dan mempublikasikan hasil penelitian tindakan kelas di masa pandemi COVID-19.

\section{METODE PELAKSANAAN}

Pendampingan ini melibatkan 24 guru SD dan 7 guru TK dari Yayasan Widiatmika. Kegiatan dilaksanakan selama 4 bulan pada semester ganjil 2020/2021, dimulai sejak bulan Oktober 2020 sampai bulan Januari 2021. Metode pelaksanaan pendampingan melalui ceramah presentasi tatap muka dan diskusi (luring dan daring). Kegiatan dilaksanakan di SD Widiatmika, Kabupaten Badung, Bali.

Bentuk kegiatan yang dilakukan adalah (1) Pemahaman tentang Penelitian Tindakan Kelas yang bisa dilaksanakan di masa pandemi COVID-19, (2) Keterampilan dalam mengembangkan instrumen penelitian Tindakan kelas, (3) Keterampilan dalam Menyusun 
proposal penelitian Tindakan kelas, (4) Kemampuan dalam menyajikan hasil penelitian secara lisan melalui kegiatan seminar, dan (5) Keterampilan dalam mempublikasikan karya ilmiah ke jurnal nasional. Bentuk kegiatan dan teknik penilaian yang dilakukan selengkapnya disajikan pada Tabel 1.

Tabel 1. Bentuk Kegiatan dan Teknik Penilaian yang Dilakukan

\begin{tabular}{llll}
\hline No & \multicolumn{1}{c}{ Uraian Kegiatan } & Bentuk Penilaian \\
\hline 1 & $\begin{array}{l}\text { Pemahaman tentang Penelitian Tindakan Kelas } \\
\text { yang bisa dilaksanakan di masa pandemi COVID-19 }\end{array}$ & Tes tertulis online \\
\hline 2 & $\begin{array}{l}\text { Keterampilan dalam mengembangkan instrumen } \\
\text { penelitian Tindakan kelas }\end{array}$ & Penilaian produk \\
\hline 3 & $\begin{array}{l}\text { Keterampilan dalam Menyusun proposal penelitian } \\
\text { Tindakan kelas }\end{array}$ & Penilaian produk \\
\hline 4 & $\begin{array}{l}\text { Kemampuan dalam menyajikan hasil penelitian } \\
\text { secara lisan melalui kegiatan seminar }\end{array}$ & Unjuk kerja \\
\hline 5 & $\begin{array}{l}\text { Keterampilan dalam mempublikasikan karya ilmiah } \\
\text { ke jurnal nasional }\end{array}$ & Portofolio \\
\hline
\end{tabular}

Untuk menentukan tingkat pemahaman dan keterampilan tersebut digunakan instrumen menggunakan google form dengan alamat https://bit.ly/pengabdian-ptk-cb. Kuesioner tentang pemahaman dan keterampilan guru dalam penelitian Tindakan kelas di masa pandemic COVID-19 disajikan seperti pada Tabel 1 Penilaian dalam bentuk skala 1 sampai 4. Penilaian dilakukan sebelum dilakukan kegiatan pendampingan (pretest) dan di akhir kegiatan pendampingan (posttest). Untuk mengetahui tingkat keberhasilan masing masing aspek penilaian tersebut digunakan tabel pengkategorian yang disajikan pada Tabel 2.

Tabel 2. Tabel Pengkategorian Hasil Kegiatan Pendampingan

\begin{tabular}{lll}
\hline No & \multicolumn{1}{c}{ Skala Penilaian } & \multicolumn{1}{c}{ Kategori } \\
\hline 1 & $88 \%-100 \%$ & Sangat baik \\
\hline 2 & $70 \%-84 \%$ & Baik \\
\hline 3 & $60 \%-69 \%$ & Cukup baik \\
\hline 4 & $50 \%-59 \%$ & Kurang baik \\
\hline 5 & $0-49 \%$ & Sangat kurang baik \\
\hline
\end{tabular}

(Sumber: Sugiyono, 2006).

Data yang diperoleh lalu dianalisis menggunakan teknik analisis deskriptif. Analisis deskriptif ini meliputi penyajian deskripsi pemahaman dan keterampilan awal guru, pemahaman dan keterampilan akhir guru. 


\section{HASIL DAN PEMBAHASAN}

\section{Hasil}

Pendampingan ini diawali dengan melakukan tes pemahaman dan keterampilan awal guru terkait penelitian tindakan kelas. Tes awal menunjukkan bahwa pemahaman dan keterampilan guru terkait penelitian tindakan kelas masih rendah. Hasil ini sejalan dengan wawancara yang dilakukan dengan kepala TK dan SD Widiatmika. Dalam Wawancara tersebut, guru-guru TK dan SD Widiatmika mempunyai masalah dalam melaksanakan penelitian tindakan kelas. Hasil tes awal pemahaman dan keterampilan guru terkait penelitian tindakan kelas tersaji pada Tabel 3.

Setelah dilakukan tes awal, dilanjutkan dengan pendampingan terkait penelitian tindakan kelas. Pendampingan ini melalui kegiatan ceramah dan presentasi terkait penelitian tindakan kelas. Materi presentasi tersebut meliputi hakekat dan jenis jenis penelitian tindakan kelas, pentingnya melaksanakan penelitian tindakan kelas bagi guru, mengembangkan instrument penelitian tindakan kelas, merencanakan, melaksakan, dan melaporkan penelitian tindakan kelas, dan teknik mempublikasikan penelitian tindakan kelas. Gambaran mengenai kegiatan ini disajikan pada Gambar 1.

Proses pendampingan selanjutnya adalah menyusun instrumen dan prosedur tindakan kelas yang meliputi Rencana Pelaksanaan Pembelajaran (RPP) yang sesuai dengan metode dan strategi yang digunakan di masa pandemi COVID-19. Pendampingan penyusunan instrumen tersebut dilaksanakan melalui diskusi pada grup salah satu aplikasi media sosial. Setelah proses ini selesai, guru diarahkan untuk melaksanakan tindakan kelas. Pelaksanaan tindakan dilakukan selama 2-3 minggu. Dalam masa pelaksanaan tindakan tersebut, guru juga melakukan diskusi untuk penyempurnaan proposal penelitian tindakan kelas yang telah disusun.

Setelah selesai melaksanakan tindakan, kemudian dilanjutkan pada tahap penyusunan laporan dan artikel publikasi. Kegiatan ini dilakukan pendampingan melalui diskusi grup media sosial. Gambaran mengenai aktivitas diskusi daring disajikan pada Gambar 2.

Kegiatan diakhiri dalam bentuk penyajian hasil penelitian tindakan kelas. Penyajian guru dilangsungkan melalui video conference. Kegiatan ini tersaji seperti pada Gambar 3. Setelah melaksanakan presentasi dan ditelaah oleh narasumber, guru kemudian mengisi tes akhir (posttest) terkait penelitian tindakan kelas. Hasil tes akhir menunjukkan ada peningkatan yang cukup signifikan pemahaman dan keterampilan guru terkait penelitian tindakan kelas. Hasil tes akhir pemahaman dan keterampilan guru terkait penelitian tindakan kelas tersaji pada Tabel 4.

Pemahaman dan keterampilan awal guru dalam penelitian tindakan kelas ada pada kategori cukup baik. Persentase tertinggi ada pada aspek pemahaman tentang Penelitian 
Tindakan Kelas yang bisa dilaksanakan di masa pandemi COVID-19 yaitu dengan skor rata rata $69 \%$. Rerata pemahaman awal guru terhadap penelitian tindakan kelas di masa pandemi COVID-19 disajikan pada Tabel 3.

Tabel 3 Rerata Pemahaman Awal Guru terhadap Penelitian Tindakan Kelas

\begin{tabular}{clcc}
\hline No & \multicolumn{1}{c}{ Uraian Kegiatan } & $\begin{array}{c}\text { Persentase } \\
(\%)\end{array}$ & Kategori \\
\hline 1 & $\begin{array}{l}\text { Pemahaman tentang Penelitian Tindakan Kelas yang bisa } \\
\text { dilaksanakan di masa pandemi COVID-19 }\end{array}$ & 69 & Cukup baik \\
\hline 2 & $\begin{array}{l}\text { Keterampilan dalam mengembangkan instrumen penelitian } \\
\text { Tindakan kelas }\end{array}$ & 65 & Cukup baik \\
\hline 3 & $\begin{array}{l}\text { Keterampilan dalam Menyusun proposal penelitian } \\
\text { Tindakan kelas }\end{array}$ & 65 & Cukup baik \\
\hline 4 & $\begin{array}{l}\text { Kemampuan dalam menyajikan hasil penelitian secara lisan } \\
\text { melalui kegiatan seminar }\end{array}$ & 62 & Cukup baik \\
\hline 5 & $\begin{array}{l}\text { Keterampilan dalam mempublikasikan karya ilmiah ke jurnal } \\
\text { nasional }\end{array}$ & 60 & Cukup baik \\
\hline Rerata & 64 & Cukup baik \\
\hline
\end{tabular}

Pendampingan dilakukan melalui kegiatan ceramah, pelatihan terbimbing, dan pelatihan mandiri baik secara tatap muka maupun daring. Ceramah yang dilakukan menggunakan media presentasi dan dihadiri oleh seluruh guru TK dan SD Widiamika yang berjumlah 31 orang. Kegiatan pemberian materi oleh narasumber disajikan pada Gambar 1.
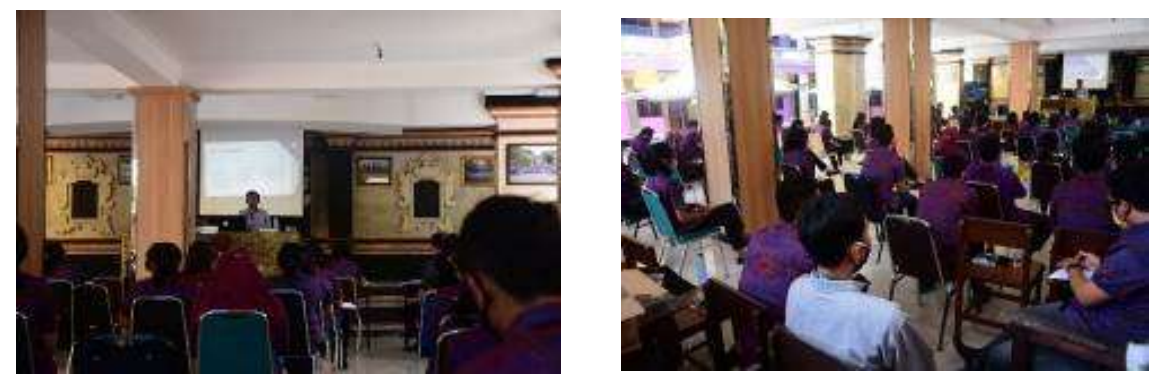

\section{Gambar 1. Pemberian Ceramah melalui Presentasi Materi tentang Penelitian Tindakan Kelas}

Kegiatan ini juga dilaksanakan secara daring, mengingat kondisi pandemi yang masih terjadi. Pendampingan daring dilaksanakan untuk mendiskusikan materi PTK, mulai dari penetapan tujuan penelitian, metode, dan cara menyajikan data. Bentuk diskusi daring disajikan pada Gambar 2.
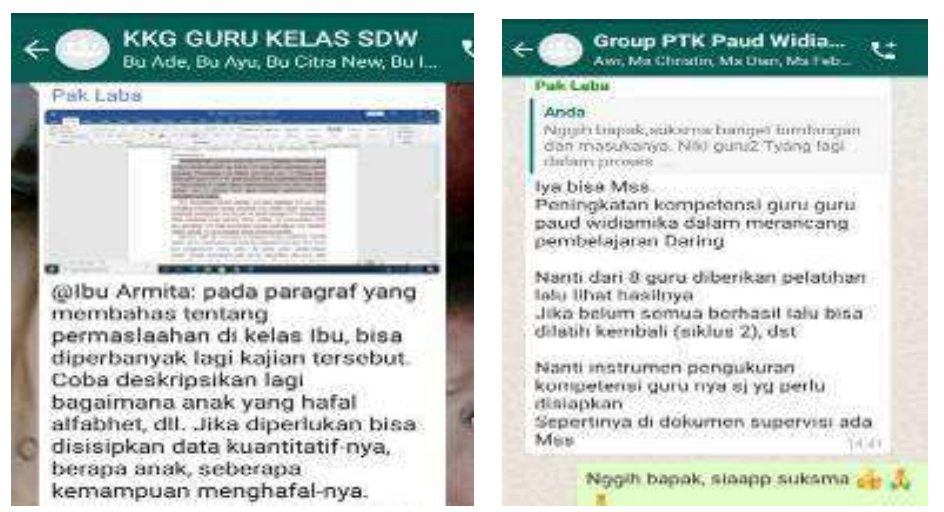

Gambar 2. Salah Satu Bentuk Pendampingan Secara Daring 
Setelah kegiatan pendampingan selesai dilaksanakan, dilanjutkan dengan diseminasi hasil penelitian. Kegiatan ini dilakukan secara daring melalui video conference. Masing masing guru menyajikan hasil karya, kemudian ditelaah oleh instruktur. Hasil kegiatan disajikan pada Gambar 3.

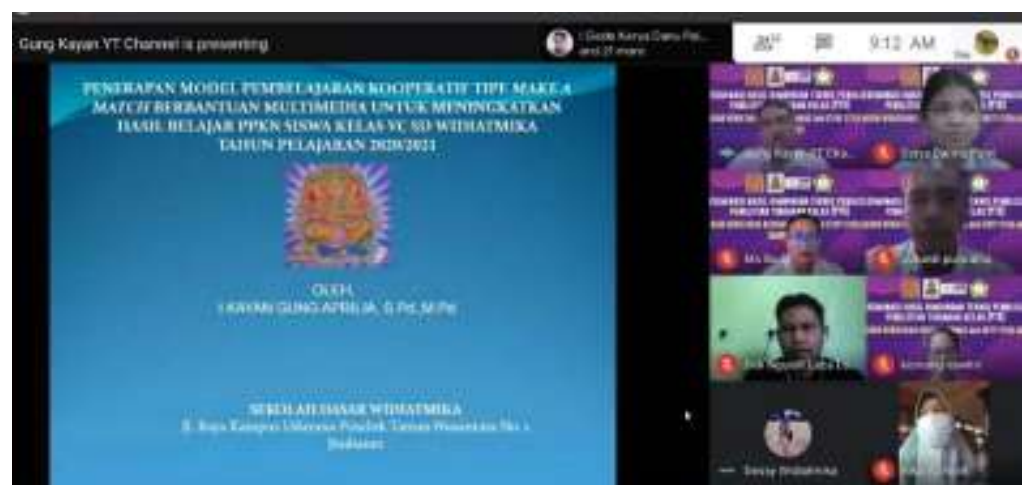

\section{Gambar 3. Hasil Penelitian Tindakan}

Pemahaman dan keterampilan akhir guru dalam penelitian tindakan kelas ada pada kategori sangat baik. Persentase tertinggi ada pada aspek Keterampilan dalam mengembangkan instrumen penelitian Tindakan kelas yaitu dengan skor rata rata 98\%. rerata pemahaman guru terhadap penelitian tindakan kelas di masa pandemi COVID-19 setelah kegiatan pendampingan disajikan pada Tabel 4.

Tabel 4 Rerata Pemahaman Guru terhadap Penelitian Tindakan Kelas di Masa Pandemi COVID-19 Setelah Kegiatan Pendampingan

\begin{tabular}{|c|c|c|c|}
\hline No & Uraian Kegiatan & Persentase (\%) & Kategori \\
\hline 1 & $\begin{array}{l}\text { Pemahaman tentang Penelitian Tindakan } \\
\text { Kelas yang bisa dilaksanakan di masa } \\
\text { pandemi COVID-19 }\end{array}$ & 96 & Sangat baik \\
\hline 2 & $\begin{array}{l}\text { Keterampilan dalam mengembangkan } \\
\text { instrumen penelitian Tindakan kelas }\end{array}$ & 98 & Sangat baik \\
\hline 3 & $\begin{array}{l}\text { Keterampilan dalam Menyusun proposal } \\
\text { penelitian Tindakan kelas }\end{array}$ & 94 & Sangat baik \\
\hline 4 & $\begin{array}{l}\text { Kemampuan dalam menyajikan hasil } \\
\text { penelitian secara lisan melalui kegiatan } \\
\text { seminar }\end{array}$ & 90 & Sangat baik \\
\hline \multirow[t]{2}{*}{5} & $\begin{array}{l}\text { Keterampilan dalam mempublikasikan } \\
\text { karya ilmiah ke jurnal nasional }\end{array}$ & 83 & Baik \\
\hline & Rerata & 92 & Sangat baik \\
\hline
\end{tabular}

\section{Pembahasan}

Dari kegiatan pengabdian ini diperoleh bahwa terjadi peningkatan kompetensi guru (pemahaman dan keterampilan) terkait penelitian Tindakan kelas. Dari hasil pengabdian ini diketahui bahwa rerata pemahaman dan keterampilan awal guru dalam penelitian Tindakan kelas ada pada kategori cukup baik. Peningkatan terjadi setelah diberikan pendampingan yang intensif melalui kegiatan presentasi, diskusi tatap muka, diskusi daring, latihan terbimbing, latihan mandiri, dan hasil, serta publikasi karya ilmiah. 
Pemahaman awal guru terkait penelitian tindakan kelas ada pada kategori cukup. Rendahnya pemahaman tersebut berhubungan dengan belum baiknya wawasan serta kemampuan guru mengembangkan pembelajaran yang dituangkan ke dalam rencana pembelajaran (Laksana dan Rawa, 2014). Seperti telah disampaikan sebelumnya, selama ini masih banyak guru menyusun rencana pembelajaran mengikuti pola guru lainnya, belum mengembangkan sendiri berdasarkan kebutuhan siswa. Selain itu, keterampilan menulis guru juga masih rendah (Senel, 2018). Kondisi ini sejalan dengan temuan Dewi, Kurniatun, dan Abubakar (2018; Sulaeman, 2018) bahwa penyusunan perencanaan pembelajaran belum sesuai kondisi belajar secara kontekstual. Dalam temuan tersebut juga diketahui bawa perencanaan pembelajaran tersebut adalah ulangan dari perangkat yang digunakan sebelumnya.

Sikap merasa tertantang ada hubungannya dengan sering mencoba megimplementasikan program/inovasi untuk mengobati masalah pembelajaran. Dalam kajian ini diketahui sikap ini pada kategori cukup. Hal ini menunjukkan bahwa guru masih rendah dalam mengimplementasikan program/inovasi pembelajaran berdasarkan masalah otentik yang terjadi di kelasnya. Kondisi ini bisa terjadi karena 1) masih belum membudayanya proses reflektif dan 2) terbatasnya wawasan. Seperti telah dijelaskan sebelumnya, guru belum terbiasa melakukan refleksi terhadap pembelajarannya. Akibatnya, guru kebingungan ketika mau mencoba perlakuan (program atau inovasi), karena masalahnya saja tidak diidentifikasi oleh guru (Prayitno, 2015).

\section{KESIMPULAN}

Kesimpulan dari kegiatan pengabdian ini adalah terjadi peningkatan pemahaman tentang hakekat penelitian tindakan, peningkatan keterampilan dalam melakukan perencanaan penelitian tindakan kelas, pengembangan instrumen penelitian tindakan kelas, teknik menyajikan data hasil penelitian, pengembangan proposal dan pelaksanaan penelitian, diseminasi/seminar hasil penelitian, dan publikasi karya ilmiah. Peningkatan kompetensi guru tersebut dari cukup baik (64\%) menjadi sangat baik (92\%).

\section{DAFTAR PUSTAKA}

Dasna, I.W., Laksana, D.N.L., \& Sudatha, G.W. (2015). Desain dan model pembelajaran inovatif dan interatif. Tangerang: UT Press

Dewi, R. S., Kurniatun, T. C., \& Abubakar. (2018). Kemampuan profesional guru dan motivasi kerja terhadap kinerja mengajar guru sekolah dasar. Jurnal Administrasi Pendidikan, 25 (1), 150-158

Ditjen Guru dan Tenaga Kependidikan. (2016). Buku I: Pengembangan keprofesian berkelanjutan. Jakarta: Ditjen GTK

Dwijayanti, R. Marlena, N., Patrikha, F. D., \& Parjono. (2017). Pelatihan penulisan karya tulis ilmiah (KTI) bagi guru-guru SMK di kabupaten Jombang. Jurnal Pemberdayaan Masyarakat Madani (JPMM), 1 (2), 249-266. 
Laksana, D.N.L. (2019a). Strategi Pembelajaran: Kajian konseptual empiris di sekolah dasar. Surabaya: Kresna Bina Insan Prima

Laksana, D.N.L. (2019b). Kesulitan belajar anak dengan gaya belajar yang berbeda dalam menghadapi pembelajaran 4.0 serta strategi yang digunakan. Dalam D.N.L. Laksana (Ed). Pembelajaran di era big data: dalam berbagai kondisi belajar (hal. 1-6). Serang: CV. AA. Rizky. https://doi.org/10.5281/zenodo.3792390.

Laksana, D.N.L., \& Rawa, N.R. (2014). Tingkat penguasaan kompetensi pedagogik guru SD di kecamatan Bajawa kabupaten Ngada. Jurnal IImiah Pendidikan Citra Bakti, 1 (1), 70-77.

Laksana, D.N.L., Dinatha, N.M., \& Upayogi, I.N.T. (2020). Pendampingan pembelajaran tematik di luar kelas berbasis minat bakat di SDI Rutosoro. Jurnal Abdimas IImiah Citra Bakti, 1 (1), 1-10. https://doi.org/10.38048/jailcb.v1i1.73

Lawe, Y.U., Laksana, D.N.L., Awe, E.Y., Wau, M.P., Noge, M.D., Wewe, M., Rawa, N.R., \& Kua, M.Y. (2020). Pendampingan guru SD dalam penyelenggaraan olimpiade MIPA tingkat SD. Jurnal Abdimas IImiah Citra Bakti, 1(2), 88-96. https://doi.org/10.38048/jailcb.v1i2.75

Noorjannah, L. (2014). Pengembangan profesionalisme guru melalui penulisan karya tulis ilmiah bagi guru profesional di SMA Negeri 1 Kauman kabupaten Tulungagung. Jurnal Humanity, 10(1), 97-114

PermenPAN RB Nomor 16. (2009). Peraturan Menteri Negara PAN dan RB Nomor 16 Tahun 2009 tentang Jabatan Fungsional Guru dan Angka Kreditnya. Jakarta: Kemen PANRB.

Rispawati \& Herianto, E. (2019). Meningkatkan profesionalisme guru madrasah melalui pelatihan penulisan karya tulis ilmiah. Jurnal Pendidikan dan Pengabdian Masyarakat, 2 (1), 133-140.

Safrizal Z.A.,Putra, D.I., Sofyan, S., dan Bimo. (2020). Pedoman umum menghadapi pandemi covid 19. Jakarta: Kementerian Dalam Negeri.

Senel, E. (2018). The integration of creative writing into academic writing skills in EFL classes. International Journal of Languages' Education and Teaching, 6(2), 115-120.

Sodiq, I., Suryadi, A., \& Ahmad, T.A. (2014). Program guru menulis: Upaya peningkatan kompetensi professional guru sejarah dalam penulisan karya ilmiah di kabupaten Semarang. Jurnal Rekayasa, 12 (1), 42-47.

Sugiyono. (2006). Metode penelitian kuantitatif kualitatif dan R\&D. Bandung: Alfabeta

Sugiyarti, S., Nurfitriani, \& Vebrian, R. (2019). Penulisan artikel ilmiah untuk guru sekolah dasar se-kabupaten Bangka. Jurnal Pengabdian Untuk Mu Negeri, 3(1), 1-5.

Sulaeman, A.A. (2018). Profil kemampuan dan kreativitas guru IPA dalam menyusun karya tulis ilmiah pada pembelajaran kurikulum 2013. Journal of Biology Education, 3(1), 1 15.

Supriyanto, A. (2017). Peningkatan kemampuan guru dalam penulisan karya ilmiah melalui pelatihan penelitian tindakan kelas. Abdimas Pedagogi, 1 (1), 1-7.

Susantini, E., Rahayu, Y.S., Budiono, D., \& Raharjo. (2016). Profil artikel ilmiah buatan guru pada pelatihan penulisan karya ilmiah bagi guru - guru di SMP lab school Surabaya. Jurnal Abdi, 1(1), 1-7. https://doi.org/10.26740/ja.v1n1.p1-7.

Yulika, F., Kasman, S., \& Masta, P. K. (2016). Peningkatan kompetensi guru melalui pelatihan penulisan karya tulis ilmiah. Jurnal Batoboh, 1 (2), 242-255. 